\title{
Plasmodium ovale infection in Malaysia: first imported case
}

Yvonne AL Lim ${ }^{1 *}$, Rohela Mahmud ${ }^{1}$, Ching Hoong Chew ${ }^{2}$, Thiruventhiran T ${ }^{3}$, Kek Heng Chua ${ }^{2}$

\begin{abstract}
Background: Plasmodium ovale infection is rarely reported in Malaysia. This is the first imported case of $P$. ovale infection in Malaysia which was initially misdiagnosed as Plasmodium vivax.

Methods: Peripheral blood sample was first examined by Giemsa-stained microscopy examination and further confirmed using a patented in-house multiplex PCR followed by sequencing.

Results and Discussion: Initial results from peripheral blood smear examination diagnosed $P$. vivax infection. However further analysis using a patented in-house multiplex PCR followed by sequencing confirmed the presence of $P$. ovale. Given that Anopheles maculatus and Anopheles dirus, vectors of $P$. ovale are found in Malaysia, this finding has significant implication on Malaysia's public health sector.

Conclusions: The current finding should serve as an alert to epidemiologists, clinicians and laboratory technicians in the possibility of finding P. ovale in Malaysia. P. ovale should be considered in the differential diagnosis of imported malaria cases in Malaysia due to the exponential increase in the number of visitors from $P$. ovale endemic regions and the long latent period of $P$. ovale. It is also timely that conventional diagnosis of malaria via microscopy should be coupled with more advanced molecular tools for effective diagnosis.
\end{abstract}

\section{Background}

Malaria is one of the most deadly parasitic diseases in the world, with an annual infection rate of 500 million cases and more than one million deaths. In Africa, malaria remains the single largest killer among children younger than 5 years of age with a mortality rate of 3,000 children per day. The latest malaria statistics recorded 243 million cases with 863, 000 deaths globally [1]. Currently, malaria can be caused by five Plasmodium species which include Plasmodium falciparum Plasmodium vivax, Plasmodium ovale, Plasmodium malariae and more recently Plasmodium knowlesi. Infections caused by P. falciparum and $P$. knowlesi may be fatal while the other species generally cause milder disease. Distribution of P. falciparum and $P$. vivax are extensively distributed in the tropics and temperate regions of the world. P. malariae is also found in these regions but is less common while cases of P. knowlesi in on the rise in Southeast Asia [2-5] and P. ovale is mainly restricted to sub-Saharan Africa [6].

\footnotetext{
* Correspondence: limailian@um.edu.my

'Department of Parasitology, Faculty of Medicine, University of Malaya, 50603 Kuala Lumpur, Malaysia

Full list of author information is available at the end of the article
}

In Malaysia, malaria remains the most common vectorborne parasitic disease. Although cases have decline in general, malaria is still a public health problem in Sabah and Sarawak. However, more recently, urban malaria cases have surged. Malaria is still clinically significant due to high mortality rates caused by $P$. falciparum in cerebral malaria cases. The recent cases of $P$. knowlesi infections in humans was first brought into international attention in 2004, when Singh et al, a Malaysian researcher, highlighted in The Lancet the occurrence of naturally-acquired $P$. knowlesi infections from macaques in human beings when they examined 208 people with malaria in the Kapit division [7]. This created great excitement in the field of malaria research and with an avalanche of information, $P$. knowlesi was subsequently labelled 'the fifth Plasmodium species that infects humans'. In the same study, two cases of $P$. ovale were also detected by nested PCR assays. Since then, no other known cases of $P$. ovale infection has been reported. Here, a case of imported $P$. ovale infection confirmed by multiplex PCR targeting the small subunit ribosomal RNA (SSU rRNA) gene is reported. The gene was sequenced and compared with other reference P. ovale isolates. 


\section{Case presentation}

A 20-year-old Nigerian male student who has been in Malaysia for the last six months presented with a history of fever associated with chills and rigors for the last four days. Other physical examination findings were unremarkable. He was diagnosed as pyrexia of unknown origin (PUO). Laboratory findings on admission revealed anaemia (haemoglobin of $10.8 \mathrm{~g} / \mathrm{dL}$ ), platelet count of $117,000 / \mathrm{ml}$ and eosinophils of $2 \%$. Blood examination of the thin smear stained with Giemsa showed enlarged infected red blood cells (RBCs) with putative parasites resembling $P$. vivax. He was treated with quinine 600 $\mathrm{mg}$ tds and doxycycline $100 \mathrm{mg}$ bd. One week after admission, the patient was well.

\section{Confirmation of Plasmodium ovale using in-house multiplex polymerase chain reaction (PCR) and sequencing}

Total genomic of this patient's blood DNA together with the Plasmodium DNA from the patient was extracted using QIAamp DNA Mini Kit (Qiagen, USA) according to the manufacturer's instructions. The extracted DNA was subjected to a patented in-house PCR targeting the SSU rRNA gene. Following that, the PCR products were electrophoresed on 3\% (w/v) ethidium bromide stained agarose gel. Results showed that the patient was infected with $P$. ovale instead of $P$. vivax, as previously diagnosed by conventional microscopy (Figure 1, lane 4). Further confirmation with PCR amplification was also carried out using genus specific primers (rPLU5/rPLU6) followed by sequencing.

\section{Analysis of sequences and phylogenetic analyses of sequence data}

Sequencing data obtained was analysed using BLAST program [8]. The BLAST result showed that the sequence information obtained has $99 \%$ similarity to SSU rRNA gene of $P$. ovale in the GenBank. For phylogenetic analyses, the sequence determined were compared with those available in GenBank and published in quality, peer-reviewed scientific journals. Sequences were trimmed and then aligned using the program Clustal $\times$

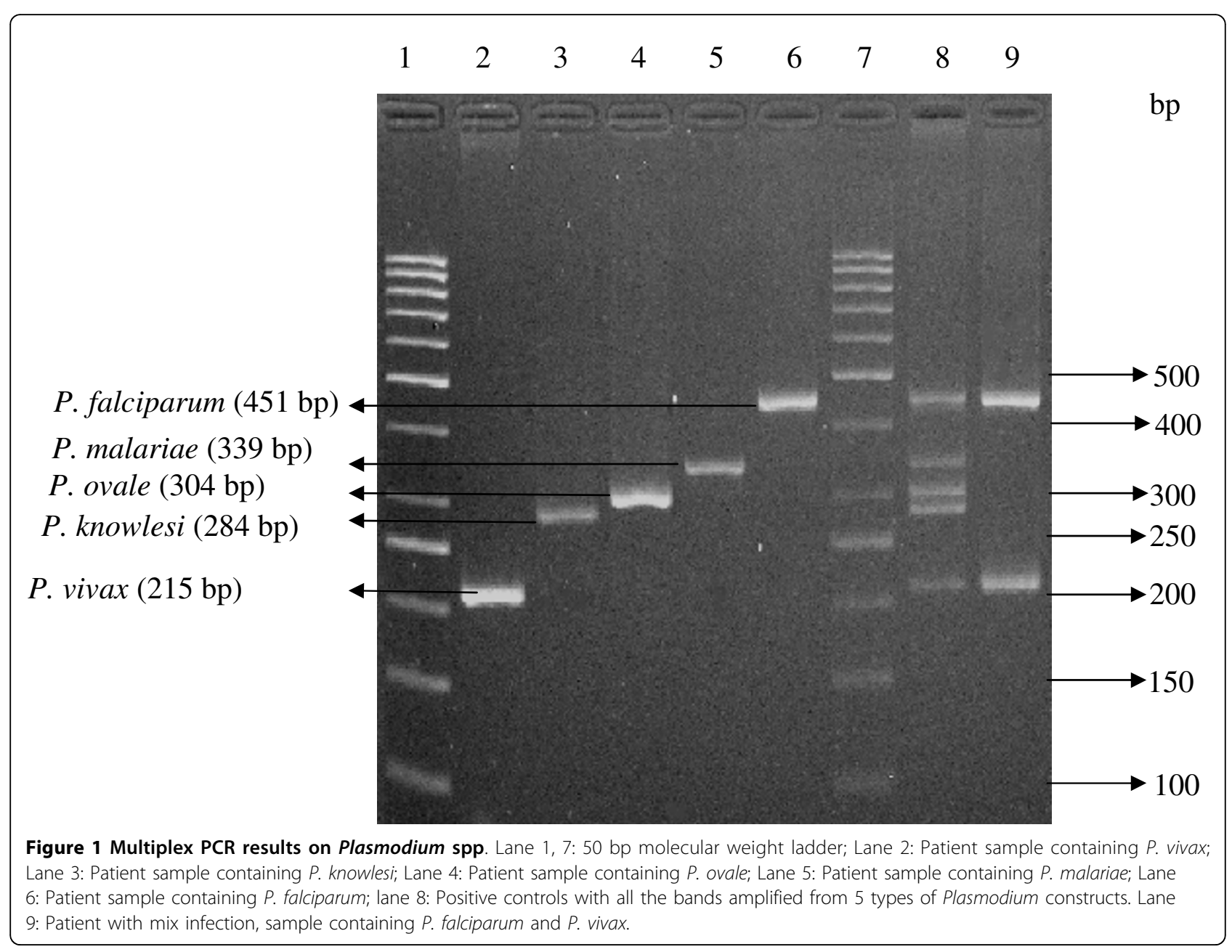


[9], and the alignments were adjusted by employing the program BioEdit [10].

The phylogenetic analysis of the sequence data was conducted using Bayesian inference (BI) and by employing the software package MrBayes v3.1.2. Posterior probabilities (pp) were calculated via 2,000,000 generations (ngen $=2,000,000$; burnin $=20,000$ ) using the Monte Carlo Markov chain method, which utilizes four simultaneous tree-building chains (nchains $=4$ ) with every $100^{\text {th }}$ tree saved (samplefreq $=100$ ). The evolutionary distance was calculated using the general time reversible evolutionary model $($ nset $=6$ ), which allows for a gamma-shaped variation in mutation rates between codons (rates $=$ gamma).

Plasmodium falciparum [GenBank accession number M19172] [11], P. vivax [GenBank accession number $\mathrm{X} 13926$ ] [12], P. malariae [GenBank accession number AF487999] [13], P. knowlesi [GenBank accession number L07560] [14], were used as the out groups in the analysis of SSU rRNA sequence data for $P$. ovale. Upon the completion of the Bayesian analysis, a $50 \%$ majority-rule consensus tree for each species was constructed in Treeview $\times$ v.0.5. Analysis of SSU rRNA sequence data inferred the patient was indeed infected with $P$. ovale and not $P$. vivax as initially diagnosed by microscopy (Figure 2).

\section{Discussion}

This is the first case of imported malarial infection caused by $P$. ovale in Malaysia. P. ovale is a cause of benign and relapsing tertian malaria and the least common among the human-infecting Plasmodium species. Besides $P$. vivax, $P$. ovale also has a dormant liver stage (with hypnozoites) following primary infection. Mature schizonts develop from the hypnozoites which later release merozoites into the blood stream causing clinical symptoms of malaria (relapsing malaria) even after many months of primary infection. However, the therapy of $P$. ovale infection is similar to that of malaria caused by $P$. vivax.

Globally, P. ovale infection causes $0.5-10.5 \%$ of all malaria cases. Although the distribution of $P$. ovale is concentrated in sub-Saharan Africa [6], P. ovale infections have also been intermittently reported in other parts of the world such as India [15-18], Papua New Guinea [19], Korea [20], Thailand [21], Spain [22] and Sri Lanka [23]. In Southeast Asia, prevalence of P. ovale infections ranged from $2.0 \%$ to $9.4 \%$, with records from southern Vietnam, Thai-Myanmar border, Lao PDR and Indonesia [24-26].

Although clinically, the treatment for $P$. ovale is the same as $P$. vivax, the specific identification of $P$. ovale is of significant public health importance. Based on enzyme-linked immunosorbent assay-based detection of infected mosquitoes, Anopheles gambiae and Anopheles funestus are the likely natural vectors of $P$. ovale in Africa [27]. Anopheles atroparvus has also been experimentally shown to be an effective mosquito host and capable of transmitting the infection to humans [28-32]. Other proven experimental hosts are Anopheles albimanus [33-35],

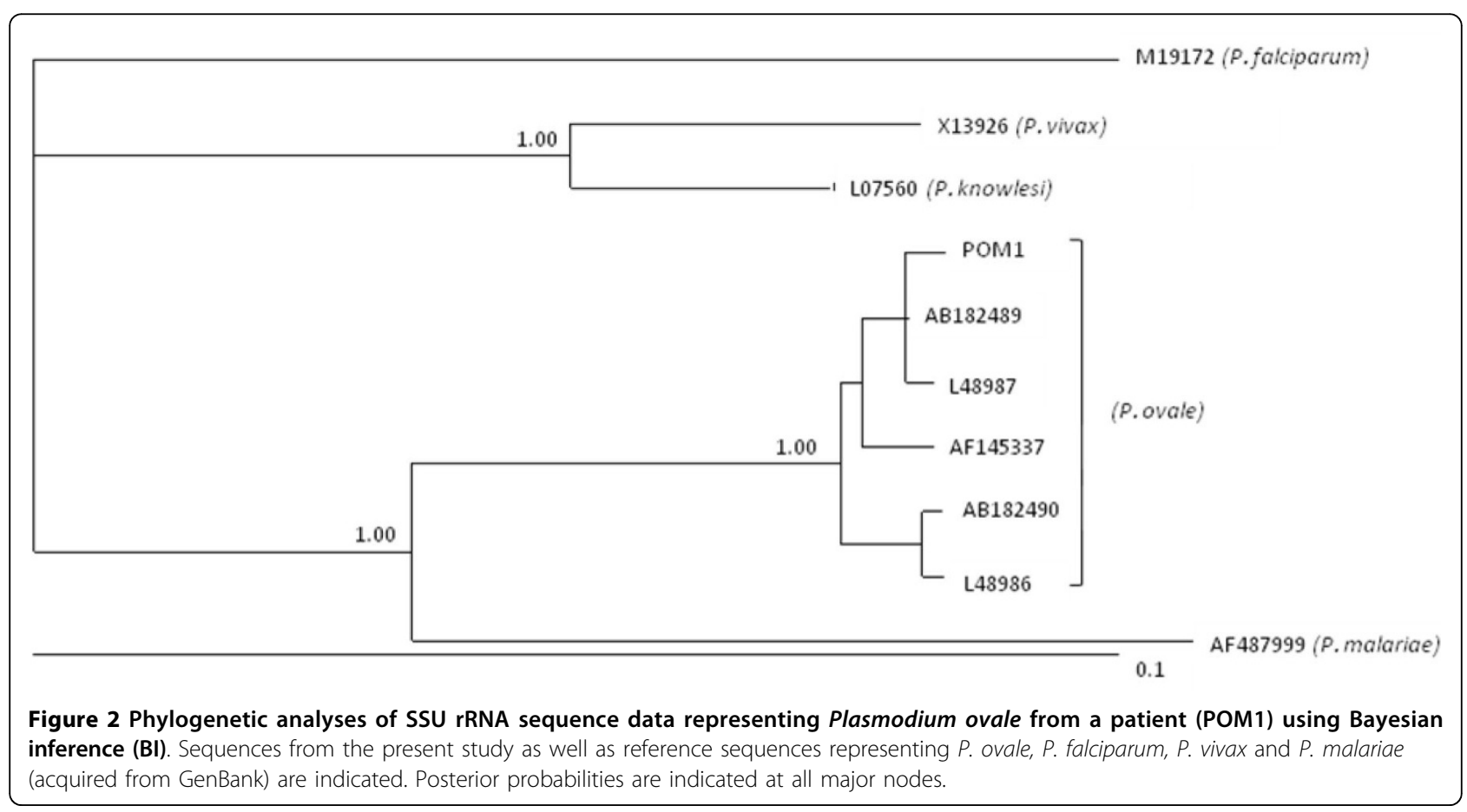


Anopheles quadrimaculatus [33,34], Anopheles freeborni [36], Anopheles maculates [36], Anopheles subpictus [32], Anopheles. stephensi and Anopheles balabacensis balabacensis (= Anopheles. dirus) [37]. In studies with the Donaldson strain of $P$. ovale, A. quadrimaculatus was the most susceptible to infection, followed by $A$. albimanus from the Florida Keys and A. albimanus from Panama [33]. In comparative studies with the West African strain, $A$. stephensi was the most susceptible, followed by $A$. freeborni, A. dirus, A. quadrimaculatus, A. maculatus, and A. albimanus [37]. Anopheles farauti has also been experimentally infected with $P$. ovale [38]. From these proven experimental hosts of $P$. ovale, two are found in Malaysia. The presence of $A$. maculatus and A. dirus in Malaysia increase the public health risk of naturally acquiring the infection. Infected $P$. ovale human host may be bitten by these vectors and the disease can be spread via the bite of the infected mosquito.

While most $P$. ovale infections in Asia were imported cases, there were at least two reports which indicated indigenous cases such as the one in India [18] and the other in Sri Lanka [23]. Since in both cases, patients involved had no travel history or receipt of blood transfusion or any blood products, $P$. ovale infection was postulated as locally acquired through infected mosquito bites $[18,23]$. These incidences highlighted two possibilities. Firstly, $P$. ovale parasites could have been prevalent in these countries but have never been detected due to high similarities between the morphology of $P$. ovale and $P$. vivax leading to misdiagnosis via conventional microscopy. Secondly, P. ovale could have first been introduced into these countries from human host who had been to Africa, where P. ovale is endemic. With the presence of suitable mosquito vectors in India and Sri Lanka, $P$. ovale could have been transmitted to other susceptible hosts. However, both articles did not mention about the vectors that were available in each respective country.

Misdiagnosis of P.vivax/P.ovale infection is possible because using routine microscopy it is difficult to morphologically distinguish $P$. vivax and $P$. ovale parasites. Both have the characteristic enlarged erythrocytes which are sometimes not obvious on thick/thin blood smears that are routinely used to detect malaria infections. There is also no difference in clinical presentation between infections with $P$. vivax and $P$. ovale, with both parasites resulting in pathognomonic chills and rigors every 48 hours.

Therefore, more advanced and reliable diagnostic techniques, such as PCR, should be utilized to provide specific identification of species, as was the case in Sri Lanka [23]. Conventionally, to identify Plasmodium species, microscopic examination of Giemsa-stained blood smears has been the diagnostic method of choice [39].
However, it is not easy to identify $P$. ovale on a blood smear, particularly when parasite numbers are low and mixed species infections are present [40]. The frequency of single $P$. ovale infection is very low even in $P$. ovaleendemic areas, while the frequency of mixed species infection involving $P$. ovale was very high. In these areas, $P$. ovale was more frequently observed using PCR methods (3.8-16.5\%) than with conventional blood smear methods $(0-0.4 \%)[24,26,41,42]$. A combined application of nucleic acid detection methods with the conventional blood smear methods should be the future recommended method especially for the identification of Plasmodium species in mixed species infections and in imported malaria cases.

This is important since there have been several recent reports of $P$. ovale infections in areas of low transmission of malaria in southern and southeast Asia $[17,24-26,43]$. It is believed that these parasites were introduced into these countries due to increased travel of tourists to or from Africa. With Malaysia's open policies in encouraging foreign workers in construction, agricultural and service sectors, besides providing lots of higher education opportunities at relatively lower cost compared to USA and UK, many foreigners including those from Africa are flocking into the country. Hence, it is paramount that clinicians and diagnostic laboratory technicians are fully aware of the possibilities of novel pathogens being introduced into the country.

This present finding essentially also highlighted the need to consider even historically distant exposure to $P$. ovale, given the potentially long latency period to relapse [44-46]. It is vital to note that an initially negative single malaria smear does not rule out $P$. ovale infection, particularly given its typical low parasitemia $[6,46]$.

\section{Conclusions}

This current finding should serve as an alert to epidemiologists, clinicians, laboratory technicians and other key stakeholders in the possibility of finding $P$. ovale in Malaysia. P. ovale should be considered as an etiology for imported malaria in Malaysia. There is a potential risk to public health since the mosquito vectors for $P$. ovale are found in Malaysia. In addition, it is also recommended that there is an urgent need to couple microscopic technique with advanced molecular methods (i.e., multiplex PCR) for accurate and specific diagnosis.

\section{Consent}

The study protocol (Reference Number: 709.2) was approved by the Ethics Committee of the University Malaya Medical Centre (UMMC), Malaysia before the commencement of the study. Written informed consent 
was obtained from the patient for publication of this case report.

\section{Acknowledgements}

This research work was funded by the University of Malaya grants (PPP. PS155-2008C and PPP: PS251-2010A)

\section{Author details}

${ }^{1}$ Department of Parasitology, Faculty of Medicine, University of Malaya, 50603 Kuala Lumpur, Malaysia. ${ }^{2}$ Department of Molecular Medicine, Faculty of Medicine, University of Malaya, 50603 Kuala Lumpur, Malaysia. ${ }^{3}$ Sunway Medical Centre Berhad, No. 5, Jalan Lagoon Selatan, Bandar Sunway, 46150 Petaling Jaya, Selangor, Malaysia.

\section{Authors' contributions}

$\mathrm{RM}$ and $\Pi$ carried out the clinical and laboratory diagnosis. CHC carried out the molecular genetic studies. YALL participated in the sequence alignment and drafted the manuscript. KHC and YALL conceived of the study, and participated in its design and coordination and drafted the manuscript. All authors read and approved the final manuscript.

\section{Competing interests}

The authors declare that they have no competing interests.

Received: 17 June 2010 Accepted: 8 October 2010

Published: 8 October 2010

\section{References}

1. WHO: World Malaria Report 2009. World Health Organization, Geneva 2009.

2. Cox-Singh J, Davis TM, Lee KS, Shamsul SS, Matusop A, Ratnam S, Rahman HA, Conway DJ, Singh B: Plasmodium knowlesi malaria in humans is widely distributed and potentially life threatening. Clin Infect Dis 2008, 15:165-171.

3. Vythilingam I, Noorazian YM, Huat TC, Jiram Al, Yusri YM, Azahari AH, Norparina I, Noorrain A, Lokmanhakim S: Plasmodium knowlesi in humans, macaques and mosquitoes in Peninsular Malaysia. Parasit Vectors 2008, $1: 26$.

4. Van den Eede P, Van HN, Van Overmeir C, Vythilingam I, Duc TN, Hungle $X$, Manh HN, Anné J, D'Alessandro U, Erhart A: Human Plasmodium knowlesi infections in young children in central Vietnam. Malar J 2009, 30:249.

5. Figtree M, Lee R, Bain L, Kennedy T, Mackertich S, Urban M, Cheng Q, Hudson BJ: Plasmodium knowlesi in human, Indonesian Borneo. Emerg Infect Dis 2010, 16:672-674.

6. Collins WE, Jeffery GM: Plasmodium ovale: parasite and disease. Clin Microbiol Rev 2005, 18:570-581.

7. Singh B, Lee KS, Matusop A, Radhakrishnan A, Shamsul SSG, Cox-Singh J, Thomas A, Conway DJ: A large focus of naturally acquired Plasmodium knowlesi infections in human beings. Lancet 2004, 363:1017-1024.

8. Altschul SF, Madden TL, Schaffer AA, Zhang J, Zhang Z, Miller W, Lipman DJ: Gapped BLAST and PSI-BLAST: a new generation of protein database search programs. Nucleic Acids Res 1997, 25:3389-3402.

9. Thompson JD, Gibson J, Plewniak F, Jeanmougin F, Higgins DG: The Clustal $X$ windows interface: flexible strategies for multiple sequence alignment aided by quality analysis tools. Nucleic Acids Res 1997, 24:4876-4882.

10. Hall BG: Phylogenetic trees made easy: a how-to manual. Sunderland, MA, U.S.A., Sinauer Associates, Inc 2004.

11. McCutchan TF, de la Cruz VF, Lal AA, Gunderson JH, Elwood HJ, Sogin ML Primary sequences of two small subunit ribosomal RNA genes from Plasmodium falciparum. Mol Biochem Parasitol 1988, 28:63-68.

12. Waters AP, McCutchan TF: Partial sequence of the asexually expressed SU rRNA gene of Plasmodium vivax. Nucleic Acids Res 1989, 17:2135.

13. Kawamoto F, Win TT, Mizuno S, Lin K, Kyaw O, Tantulart IS, Mason DP, Kimura M, Wongsrichanalai C: Unusual Plasmodium malariae-like parasites in southeast Asia. J Parasitol 2002, 88:350-357.

14. Waters AP, Higgins DG, McCutchan TF: Evolutionary relatedness of some primate models of Plasmodium. Mol Biol Evol 1993, 10:914-923.

15. Mukherjea AK, Chatterjee PK, Paul SC: A case of Plasmodium ovale infection. Bull Calcutta Sch Trop Med 1966, 14:88-89.
16. Jambulingam P, Mohapatra SS, Das LK, Das PK, Rajagopalan PK: Detection of Plasmodium ovale in Koraput district, Orissa state. Indian J Med Res 1989, 89:115-116.

17. Mishra B, Mirdha BR, Samantray JC: Plasmodium ovale malaria in Delhi. Indian J Pediatr 1999, 66:143-144.

18. Marathe A, Date V, Shah HN, Tripathi JR: Plasmodium ovale - a case report from Gujarat. J Vect Borne Dis 2006, 43:206-208.

19. Hombhanje FW: Plasmodium ovale species in Papua New Guinea-lest we forget. PNG Med J 1998, 41:116-118.

20. Han TH, Kim BN, Seong HK: A case of imported Plasmodium ovale malaria. J Korean Med Sci 2006, 21:932-935.

21. Coldren RL, Jongsakul K, Vayakornvichit S, Noedl H, Fukudas MM: Apparent relapse of imported Plasmodium ovale malaria in a pregnant woman. Am J Trop Med Hyg 2007, 77:992-994.

22. Rojo-Marcos G, Cuadros-González J, Mesa-Latorre JM, Culebras-López AM, de Pablo-Sánchez R: Acute respiratory distress syndrome in a case of Plasmodium ovale malaria. Am J Trop Med Hyg 2008, 79:391-393.

23. Wickremasinghe R, Galapaththy GN, Fernando WA, de Monbrison F, Wijesinghe RS, Mendis KN, Picot S, Ringwald P, Wickremasinghe AR: An indigenous case of Plasmodium ovale infection in Sri Lanka. Am J Trop Med Hyg 2008, 78:206-207.

24. Kawamoto F, Liu Q, Ferreira MU, Tantular IS: How prevalent are Plasmodium ovale and P. malariae in east Asia? Parasitol Today 1999 15:422-426.

25. Toma H, Kobayashi J, Vannachone B, Arakawa T, Sato $Y$, Nambanya S, Manivong K, Inthakone S: Plasmodium ovale infections detected by PCR assay in Lao PDR. Southeast Asian J Trop Med Public Health 1999, 30:620-622.

26. Win TT, Lin K, Mizuno S, Zhou M, Liu Q, Ferreira MU, Tantular IS, Kojima S, Ishii A, Kawamoto F: Wide distribution of Plasmodium ovale in Myanmar. Trop Med Int Health 2002, 7:231-239.

27. Beier MS, Schwartz IK, Beier JC, Perkins PV, Onyango F, Koros JK Campbell GH, Andrysiak PM, Brandling-Bennett AD: Identification of malaria species by ELISA in sporozoite and oocyst infected Anopheles from western Kenya. Am J Trop Med Hyg 1988, 39:323-327.

28. James SP, Nicol WD, Shute PG: $P$. ovale passage through mosquitoes and successful transmission by their bites. Ann Trop Med Parasitol 1932, 26:139-145.

29. James SP, Nicol WD, Shute PG: Plasmodium ovale Stephens 1922. Parasitol 1933, 25:87-95

30. Sinton JA, Hutton EL, Shute PG: Studies of infections with Plasmodium ovale. I. Natural resistance to ovale infections. Trans $R$ Soc Trop Med Hyg 1939, 32:751-762.

31. Shute $P G$, Maryon M: A study of human malaria oocysts as an aid to species diagnosis. Trans R Soc Trop Med Hyg 1952, 46:275-292.

32. Garnham PCC: Malaria parasites and other haemosporidia. Blackwell Scientific Publications, Oxford, England 1966.

33. Jeffery GM: The Donaldson strain of malaria 3 . The infection in the mosquito. Am J Trop Med Hyg 1954, 3:651-659.

34. Jeffery GM, Young MD, Wilcox A: The Donaldson strain of malaria 1. History and characterization of the infection in man. Am J Trop Med Hyg 1954, 3:628-637.

35. Jeffery GM, Wilcox A, Young MD: A comparison of West African and West Pacific strains of Plasmodium ovale. Trans R Soc Trop Med Hyg 1955. 49:168-175.

36. Chin W, Contacos PG, Buxbaum JN: The transmission of a West African strain of Plasmodium ovale by Anopheles freeborni and Anopheles maculatus. Am J Trop Med Hyg 1966, 15:690-693.

37. Coatney GR, Collins WE, Warren M, Contacos PG: The primate malarias U. S Government Printing Office, Washington, D.C 1971

38. Collins WE, Sullivan JS, Nace D, Williams T, Kendall J, Sullivan JJ, Galland GG, Grady KK, Bounngaseng A: Experimental infection of Anopheles farauti with different species of Plasmodium. J Parasitol 2002, 88:295-298.

39. Warhurst DC, Williams JE: Laboratory diagnosis of malaria. J Clin Pathol 1996, 49:533-538.

40. Richie TL: Interactions between malaria parasites infecting the same vertebrate host. Parasitol 1988, 96:607-639.

41. Snounou G, Viriyakosol S, Zhu XP, Jarra W, Pinheiro L, do Rosario VE, Thaithong S, Brown KN: High sensitivity of detection of human malaria parasites by the use of nested polymerase chain reaction. Mol Biochem Parasitol 1993, 61:315-320. 
42. May J, Mockenhaupt FP, Ademowo OG, Falusi AG, Olumese PE, Bienzle U, Meyer CG: High rate of mixed and subpatent malarial infections in southwest Nigeria. Am J Trop Med Hyg 1999, 61:339-343.

43. Incardona S, Chy S, Chiv L, Nhem S, Sem R, Hewitt S, Doung S, MercereauPuijalon $\mathrm{O}$, Fandeur T: Large sequence heterogeneity of the small subunit ribosomal RNA gene of Plasmodium ovale in Cambodia. Am J Trop Med Hyg 2005, 72:719-724.

44. Davis TM, Singh B, Sheridan G: Parasitic procrastination: late-presenting ovale malaria and schistosomiasis. Med J Aust 2001, 175:146-148.

45. Collins WE, Jeffery GM: A retrospective examination of sporozoiteinduced and trophozoite-induced infections with Plasmodium ovale: development of parasitologic and clinical immunity during primary infection. Am J Trop Med Hyg 2002, 66:492-502.

46. Bottieau E, Clerinx J, Van Den Enden E, Van Esbroeck M, Colebunders R, Van Gompel A, Van Den Ende J: Imported non-Plasmodium falciparum malaria: a five-year prospective study in a European referral center. Am J Trop Med Hyg 2006, 75:133-138.

doi:10.1186/1475-2875-9-272

Cite this article as: Lim et al:: Plasmodium ovale infection in Malaysia: first imported case. Malaria Journal 2010 9:272.

\section{Submit your next manuscript to BioMed Central} and take full advantage of:

- Convenient online submission

- Thorough peer review

- No space constraints or color figure charges

- Immediate publication on acceptance

- Inclusion in PubMed, CAS, Scopus and Google Scholar

- Research which is freely available for redistribution

Submit your manuscript at www.biomedcentral.com/submit
C Biomed Central 